\title{
EVALUATION IMPLEMENTATION OF REVOLVING FUND PROGRAM SAMISAKE IN BENGKULU
}

\section{EVALUASI IMPLEMENTASI PROGRAM DANA BERGULIR SAMISAKE DI KOTA BENGKULU Jatmiko Yogopriyatno Department of Public Administration, Faculty of Social and Political Science, University of Bengkulu \\ Email: ivogop@unib.ac.id; jatmikoyoga.p@gmali.com}

\begin{abstract}
How to Cite :
Yogopriyatno, Jatmiko. (2020). Evaluasi Implementasi Program Dana Bergulir Samisake di KLota Bengkulu. Sengkuni Jurnal- Social Sciences and Humanities. DOI: https://doi.org/10.37638/sengkuni.1.1.1-11
\end{abstract}

\section{ARTICLE HISTORY}

Received [1 Maret 2020]

Revised [26 Maret 2020]

Accepted [5 April 2020]

\section{KEYWORDS}

Evaluation implementation, Program Revolving Fund, Samisake.

This is an open access article under the $C C-B Y-S A$ license

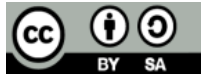

\section{ABSTRAK}

Terdapat dua kajian dalam penelitian ini yaitu; analisis ketercapaian implementasi, dan perbaikan program kedepannya. Penelitian ini menggunakan metode kualitatif deskriptif. Analisis data menggunakan analytical subprocesses and practices yakni (1) reduksi data dan pola identifikasi dan (2) penarikan kesimpulan dan memaparkan kesimpulan tersebut. Berdasarkan hasil penelitian diketahui bahwa Pertama: dalam dimensi Implementasi Program teridentifikasi bahwa (a) program ini telah memenuhi kriteria ketepatan program. (b) Output program berupa pendampingan teknis dan jumlah penerima manfaat program sebanyak 9294 orang dengan keterserapan anggaran sebesar $\mathrm{Rp}$ 13.649.000.000,00. (c) Short-term outcome menghasilkan sebanyak 11,587 tenaga kerja, dan menghasilkan sebanyak 8,322 unit usaha. (d) Terjadi ketidak sesuaian implementasi terhadap desain awal program. (e) Hambatan implementasi program berupa kesiapan sumber daya, dukungan peraturan, kondisi lingkungan kebijakan, dan ketidak patuhan birokrat pelaksana. Kedua; Pada dimensi perbaikan program diketahui bahwa: (a) secara matematis program ini telah menunjukan kinerja yang optimal dengan persentase short-term outcome sebesar $23 \%$. (b) Terdapat tiga wilayah modifikasi program yaitu; perbaikan mekanisme penyaluran dana bergulir, penyempurnaan dimensi pendampingan program, dan pemenuhan staff pelaksana baik dari segi kualitas maupun kuantitas personel. (c) Adapun modifikasi program dalam tahap perumusan raperda oleh pemerintah.

\section{ABSTRACT}

There are two studies in this research; achievement analysis implementation, and improvement of the future program. This study uses descriptive qualitative method. Analysis of data using analytical subprocesses and practices: (1) reduction of data and identification of patterns and (2) conclusion and present their conclusions. Based on 
the survey results revealed that First: the dimensions of Program
Implementation identified that (a) the program has met the criteria for
program correctness. (b) Output in the form of technical assistance
programs and the number of beneficiaries as many as 9294 people
with absorption budget of Rp $13,649,000,000.00$. (c) Short-term
outcome of labor to produce as much as $11.587,8.322$ and generate
as much business units. (d) There was a discrepancy implementation
of the initial design of the program. (e) Barriers to implementation of
the program in the form of readiness resources, regulatory support,
policy environment, and disobedience bureaucrats executor. Second;
On-dimensional improvement program known that: (a) mathematically
program has shown optimal performance with the percentage of short-
term outcome by $23 \%$. (b) There are three program areas that are the
focus in the modification, namely; repair mechanism of revolving funds,
enhanced dimensional mentoring programs, and compliance executive
staff in terms of both quality and quantity of personnel. (c) The
development of the modification program in the stage of formulation
government.

\section{PENDAHULUAN}

Pemerintah Kota Bengkulu merilis program Program Dana Bergulir Samisake sebagai kebijakan pro poor yang bertujuan untuk memutus mata rantai kemiskinan yang ada di Kota Bengkulu. Program ini merupakan terobosan yang dilaksanakan oleh Pasangan Walikota Bengkulu (Helmi Hasan dan Wakil Walikota Bengkulu Patriana Sosialinda), dengan merujuk pada kondisi kemiskinan di kota Bengkulu dan sebagai bentuk implementasi visi APBD untuk rakyat.

Program ini dibentuk berdasarkan Peraturan Daerah Nomor 12 Tahun 2013 Tentang Pengelolaan Dana Bergulir Samisake, di mana dalam Peraturan Daerah tersebut ditetapkan bahwa pengelolaan dana bergulir Samisake dilaksanakan oleh UPTD pada Dinas. UPTD tersebut berstatus sebagai Badan Layanan Umum Daerah dan dalam pengelolaan dana bergulir Samisake bekerja sama dengan Lembaga Keuangan Mikro (LKM) pada setiap kelurahan.

Kemudian terkait dengan realisasi Perda tersebut diatur dalam Petunjuk Pelaksanaan Pengelolaan dana Bergulir Samisake dan Perwal Nomor 28 Tahun 2013 tentang Petunjuk Teknis Pengelolaan Dana Bergulir Samisake. Adapun yang menjadi Visi Samisake Kota Bengkulu yaitu; "Mewujudkan Kesejahteraan Masyarakat Kota Bengkulu melalui Peningkatan Pendapatan yang Berkeadilan Sosial".

Selanjutnya apabila kita melihat Program Samisake Kota Bengkulu pasca peluncurannya pada tanggal 02 Desember 2013, program ini telah berhasil menyalurkan dana sebesar Rp 13,649 miliar dari target Rp 19 miliar, adapun sisanya akan dianggarkan kembali pada tahun 2015. Hal ini berarti kucuran dana Samisake yang telah diterima oleh masyarakat yang menjadi targett group policy mencapai $71,837 \%$. Apabila kita melihat dari perspektif implementasi kebijakan terkait dengan proses penyaluran program, maka implementor telah berhasil melaksanakan share program dengan baik.

Namun dalam proses implementasi program yang dilaksanakan oleh Pemerintah Kota Bengkulu menghadapi berbagai kendala seperti ketidakkonsistenan penyalulan dana, ketidakadilan dalam penentuan kelompok sasaran, dan pungutan liar dalam realisasi dana Samisake menjadi isu publik di kota Bengkulu. 
Selanjutnya dengan melihat berbagai permasalahan yang muncul ke permukaan dan menjadi isu publik di kalangan masyarakat Kota Bengkulu terkait dengan implementasi Program dana bergulir Samisake menjadi penting untuk dilakukan kajian evaluasi sebagai bentuk dari rekomendasi kebijakan dana bergulir samisake yang ada di Kota Bengkulu. Hal ini mengingat program dana bergulir samisake sangat dibutuhkan keberadaannya oleh masyarakat Kota Bengkulu karena merupakan suatu harapan baru untuk meningkatkan kualitas hidup melalui penciptaan lapangan kerja dan akses biaya permodalan bagi masyarakat. Kondisi ini menjadikan peneliti tertarik mengkaji permasalahan implemetasi kebijakan ini dalam sebuah penelitian dengan judul "Evaluasi Implementasi Program Dana Bergulir Samisake di Kota Bengkulu".

Berdasarkan pada latar belakang dan dikaitkan dengan judul penelitian di atas, maka rumusan masalah dalam penelitian ini yakni; "Bagaimanakah Kinerja Implementasi Program Dana Bergulir Samisake yang di jalankan di Kota Bengkulu?".

Adapun yang menjadi tujuan dalam penelitian ini adalah sebagai berikut:

1. Untuk mengevaluasi implementasi/pelaksanaan program Dana Bergulir Samisake di Kota Bengkulu, dan

2. Untuk memberikan rekomendasi/perbaikan kepada Pemerintah Kota Bengkulu terkait dengan proses implementasi Program Dana Bergulir Samisake kedepannya.

\section{LANDASAN TEORI}

\section{Evaluasi Implementasi Program Dana Bergulir Samisake di Kota Bengkulu}

Pengkajian tentang evaluasi Implementasi Program Dana Bergulir Samisake di Kota Bengkulu ini ditujukan untuk menjawab berbagai permasalahan yang muncul ke permukaan dan menjadi isu publik di kalangan masyarakat Kota Bengkulu terkait dengan implementasi Program Samisake sebagaimana telah penulis paparkan pada sub bab pendahuluan.

Dalam pemikiran yang dikemukakan oleh Paulumbo dalam Parsons (2011: 549) menyebutkan bahwa: "Evaluasi yang sedang dilakukan ketika kebijakan sedang diimplementasikan merupakan analisis tentang seberapa jauh program diimplementasikan dan apa kondisi yang bisa meningkatkakan keberhasilan implementasi".

Dalam penelitian ini, peneliti mengadopsi dua aspek dari Model kronologis yang dikemukakan oleh Arnold Love dalam Wholey (2004:66) yakni analisis kesesuaian implementasi program, dan perbaikan/rekomendasi program kedepannya untuk melakukan kajian evaluasi implementasi program samisake yang telah dilaksanakan oleh Pemerintah Kota Bengkulu, sebagaimana dipaparkan sebagai berikut:

\section{a) Penyampaian/Implementasi Program}

Dalam pandangan yang dikemukakan oleh Arnold Love dalam Wholey (2004: 80) bahwa "inti dari evaluasi implementasi adalah evaluasi dari implementasi program tersebut, hal ini mengandung dua komponen utama yakni: cakupan program dan proses pelayanan". Cakupan program digunakan untuk mengukur partisipasi yang ditunjukan kelompok sasaran dari program yang dibuat, dan mengidentifikasi kemungkinan bias yang akan muncul dalam memilih kelompok sasaran, serta partisipasi oleh orang yang salah. Oleh karena itu untuk menunjang keberhasilan dari program yang diimplementasisakan, peran dari implementor dalam dalam implementasi menjadi faktor yang penting untuk ketercapaian program. 
Dalam konteks penelitian ini, proses implementasi program dana bergulir Samisake di Kota Bengkulu akan dilihat sebagai sebuah bentuk evaluasi terhadap proses implementasi program dana bergulir samisake kepada masyarakat Kota Bengkulu. Dengan mendasarkan pada model kronologis, maka indikator pada aspek penelitian ini adalah sebagai berikut:

$>$ Apakah program dana bergulir samisake di Kota Bengkulu diimplementasikan kepada kelompok sasaran dengan benar?

> Apakah penerima program dana bergulir samisake di Kota Bengkulu menolak/menerima program, (apa alasannya)?

> Apakah rencana program dana bergulir samisake di Kota Bengkulu diimplementasikan berdasarkan rencana awal yang telah dibuat?

> Apakah program dana bergulir samisake di Kota Bengkulu menghasilkan output yang diharapkan sesuai rencana?

> Apakah program dana bergulir samisake telah memenuhi standart kualitas sebagaimana dengan desain awal yang telah direncanakan?

> Apakah program dana bergulir samisake di Kota Bengkulu menghasilkan dampak jangka pendek bagi target group?

> Hambatan-hambatan apa saja yang dihadapi dalam implementasi program dana bergulir samisake di Kota Bengkulu?

> Perbedaan-perbedaan apa saja yang ditemui terkait dengan hambatanhambatan tersebut?

\section{b) Perbaikan/rekomendasi program kedepannya}

Pada tahap perbaikan/rekomendasi program, evaluasi implementasi digunakan untuk memperbaiki desain program, memodifikasi rencana program, memperkuat pelayanan, dan memberikan pemahaman terhadap pelaksana program yang lebih besar tentang hubungan operasional program dan hasil. Melalui evaluasi implementasi kita dapat mengetahui bahwa program yang dilaksanakan telah mencapai target sasaran yang ditentukan ataukah belum, setelah rangkaian proses tersebut dilaksanakan maka proses rekomendasi/ pemantauan terhadap kebijakan dilaksanakan. Dalam konteks penelitian tentang evaluasi implementasi program dana bergulir samisake, rekomendasi dari penerima program yang dihasilkan dalam penelitian ini akan menjadi alat penting lain untuk meningkatkan pelaksanaan program. Adapun indikator yang digunakan dalam aspek ini yaitu:

> Apakah program dana bergulir samisake di Kota Bengkulu dapat mencapai tujuan dalam target implementasi?

$>$ Apakah terdapat kejadian-kejadian baik interent maupun eksterent yang mempengaruhi implementasi staff dan kelompok sasaran?

$>$ Apakah kekuatan dan kelemahan dari program program sebelum diimplementasikan, bagaimanakah hubungan keterkaitannya?

$>$ Pada wilayah apa saja yang membutuhkan struktur perbaikan terkait dengan implementasi program Samisake di Kota Bengkulu?

> Apakah usaha untuk memperbaiki program berhasil, bagaimanakah output kebijakan atau modifikasi program yang dihasilkan?

\section{Kerangka Pikir Penelitian}

Berdasarkan fenomena yang terjadi dalam proses implementasi program dana bergulir samisake di tingkat lapangan, menjadi penting untuk dilakukan kajian evaluasi implementasi sebagai bentuk dari rekomendasi kebijakan. Sehingga dengan merujuk 
pada teori yang di bangun dalam penelitian ini, maka peneliti operasionalkan dalam model kerangka pikir sebagai berikut:

\section{Gambar 1 Kerangka Pikir Penelitian}

Model Kronologis Arnold Love
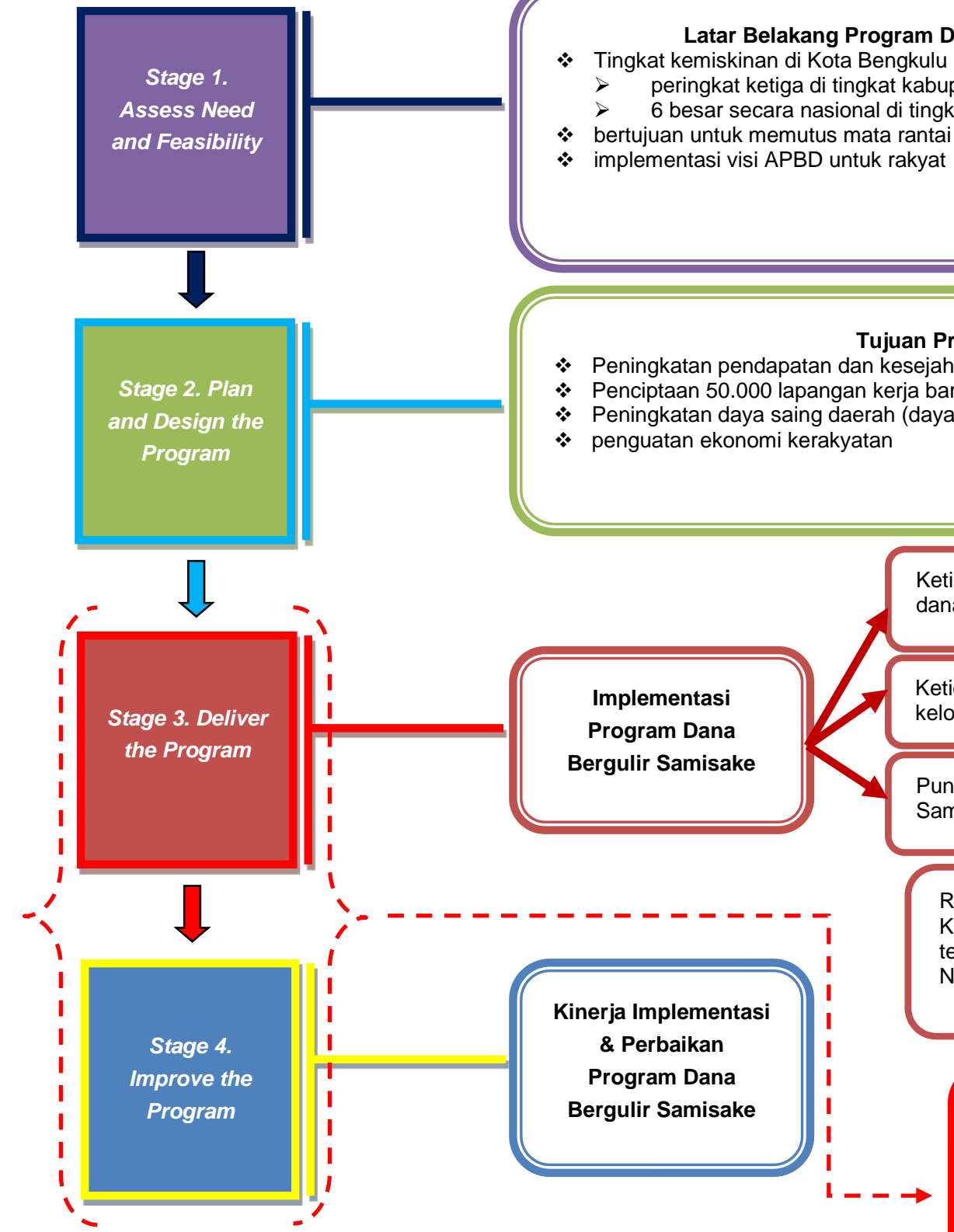

Tinjauan Program Dana Bergulir Samisake

Latar Belakang Program Dana Bergulir Samisake:

* Tingkat kemiskinan di Kota Bengkulu

$>$ peringkat ketiga di tingkat kabupaten kota

> 6 besar secara nasional di tingkat provinsi

* bertujuan untuk memutus mata rantai kemiskinan

* implementasi visi APBD untuk rakyat

\section{Tujuan Program}

* Peningkatan pendapatan dan kesejahteraan masyarakat

* Penciptaan 50.000 lapangan kerja baru

* Peningkatan daya saing daerah (daya saing usaha dan investasi)

* penguatan ekonomi kerakyatan
Ketidakkonsistenan dana

Ketidakadilan dalam penentuan kelompok sasaran

Pungutan liar dalam realisasi dana Samisake

\section{Rekomendasi}

dari

Kemendagri dan BPK RI

tentang revisi perda

No.12 Tahun 2013

penyalulan

.

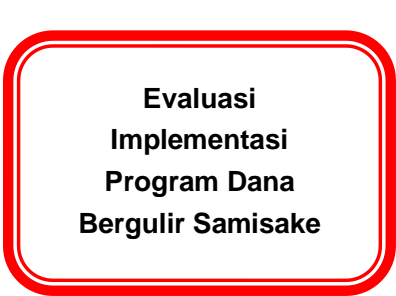




\section{METODE PENELITIAN}

Dalam penelitian ini menggunakan metode kualitatif deskriptif, proses penggalian data dilaksanakan dengan metode wawancara terhadap sejumlah informan kunci dan dokumentasi data di lapangan.

Pengumpulan data dilakukan dengan observasi, wawancara, dan dokumentasi. Analisis data menggunakan analytical subprocesses and practices yang dikembangkan oleh Sharon L. Caudle dalam penelitian evaluasi program. analisis data ini terdiri dari dua subproses utama: (1) reduksi data dan pola identifikasi yakni reduksi data dilaksanakan dengan mengidentifikasi pola, mengkategorikan, tabulasi data, membandingkan, atau merekombinasi data yang diperoleh di lapangan smpai kepada tahapan dispay/penyajian data, dan (2) penarikan kesimpulan dan memaparkan kesimpulan tersebut, proses ini berfungsi untuk mencari temuan yang relevan dan signifikan dalam pola data yang berhasil diidentifikasi, termasuk menafsirkan temuan lapanan.

\section{HASIL DAN PEMBAHASAN}

\section{Implementasi Program}

Dalam dimensi Implementasi Program teridentifikasi sebagai berikut; Pertama; berkaitan dengan ketepatan program masuk dalam kategori yang baik hal ini teridentifikasi dari terpenuhinya kriteria tepat sasaran yang dilihat dari akurasi program yang telah sesuai dengan pedoman di dalam perda samisake. Kemudian pada indikator ketepatan jumlah diketahui bahwa program telah memenuhi ketepatan jumlah sasaran program dan adanya kesesuaian realisasi anggaran yang diimplementasikan.Terakhir pada indikator ketepatan waktu, program ini berjalan sesuai dengan rencana yang ditentukan walaupun pada praktiknya proses pencairan anggaran memiliki rentang waktu yang sangat singkat, dan adanya konsistensi waktu yang digunakan dalam melaksanakan realisasi program, dimana para pelaksana program menggunakan alokasi waktu dalam proses realisasi dana bergulir samisake sesuai dngan tenggang waktu yang telah ditentukan.

Kedua; Sikap kelompok sasaran terhadap implementasi program berada pada dua kutub yakni positif dan negatif. Sikap positif ditunjukan oleh kelompok sasaran yang merasa kepentingan mereka telah terakomodasi oleh adanya intervensi program. Sedangkan sikap negatif/penolakan muncul dari kelompok masyarakat yang merasa kepentingannya belum terakomodasi dalam kebijakan, karena mereka belum memperoleh pinjaman dari intervensi program dana bergulir samisake yang disediakan oleh Pemerintah Kota Bengkulu.

Ketiga; dalam proses implementasi program dana bergulir samisake tidak sesuia dengan rencana awal program. Hal ini dillihat dari proses pengguliran program yang langsung di alokasikan dari dana APBD melalui Kas Daerah langsung kepada LKM. Padahal dalam konsep desain implementasi program sebagaimana tertuang di dalam perda bahwa secara teknis kegiatan pengelolaan dana bergulir dilaksanakan melalui model Badan Layanan Umum Daerah (BLUD). Namun dalam perjalalanan implementasi program, kegiatan pengelolaan dana bergulir dilaksanakan langsung dari Kas Daerah langsung kepada LKM tanpa menunggu kesiapan BLUD secara penuh. 
Sehingga kewenangan UPTD dalam pengelolaan dana bergulir baru sebatas channeling (pengkoordinasi program di tingkat lapangan).

\section{Gambar 2 Ketidakonsistenan Sistem Penganggaran Dana Bergulir Samisake}

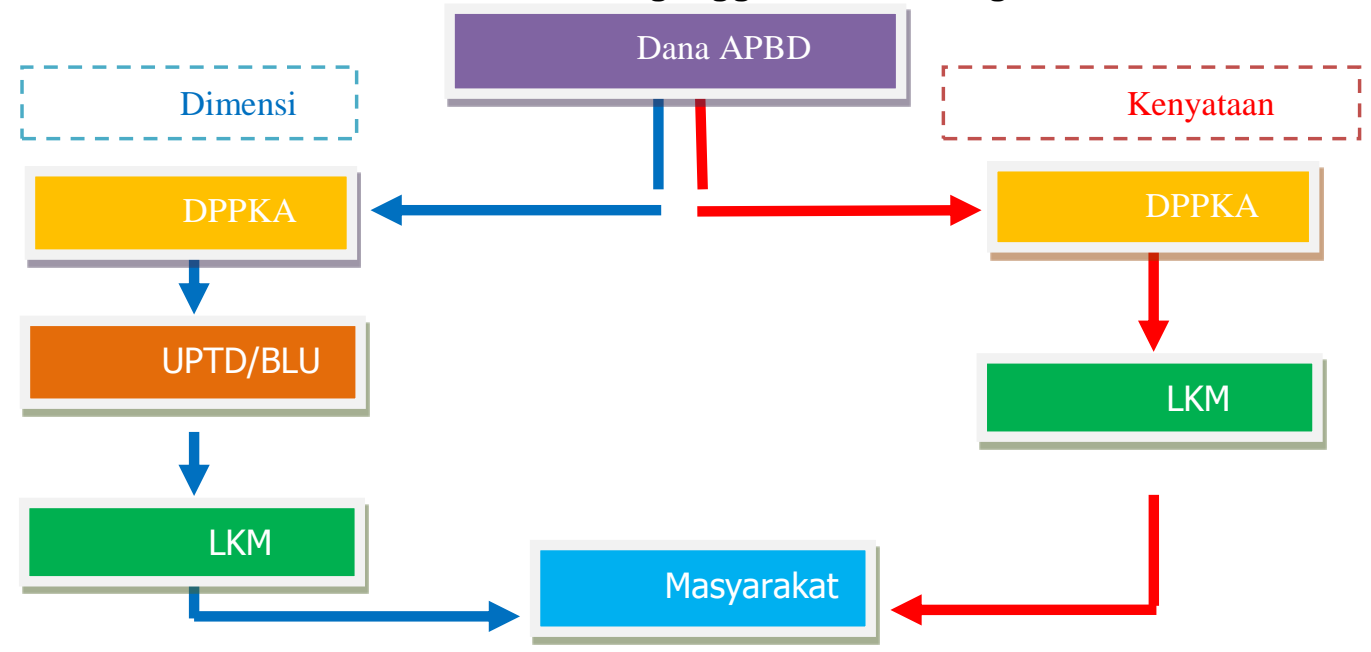

Keempat; Dimensi output program teridentifikasi bahwa; jenis layanan yang diberikan kepada kelompok sasaran melalui program dana bergulir samisake berbentuk pendampingan teknis, program telah menghasilkan output berupa penerima manfaat program sebanyak 9294 orang, dan terakhir berkaitan dengan keterserapan jumlah dana oleh kelompok sasaran dari adanya intervensi program yakni sebesar $\mathrm{Rp}$ 13.649.000.000,00.

Kelima; pada dimensi ketercapaian standar output bahwa secara teknis Pemerintah Kota Bengkulu tidak menargetkan pencapaian program secara penuh sebagaimana janji politik yang dikemukakan oleh walikota dengan penciptaan 50.000 lapangan kerja. Karena dengan sifat dana bergulir yang disalurkan, pemenuhan ketercapaian program tidak dapat ditempuh dengan laporan kinerja di atas kertas saja melainkan terdapat mekanisme kerja yang harus dipertanggungjawabkan dari aspek pengelolaan program. Karena dengan penyediaan anggaran dana sebesar 19 miliar hanya mampu terserap 13, 649 miliar, artinya tingkat kemampuan baik pengelola maupun masyarakat belum memadai untuk mengelola anggaran dalam skala yang lebih besar.

Keenam; pada dimensi dampak jangka pendek program yang diidentifikasi dari tiga komponen yakni; a)Short-term outcome pada jumlah tenaga kerja telah menghasilkan jumlah tenaga kerja sebanyak 11,587 orang, b) Short-term outcome pada jumlah usaha telah menghasilkan jumlah usaha sebanyak 8,322 unit usaha.

Ketujuh; yang berkaitan dengan hambatan implementasi program teridentifikasi empat faktor yang menjadi penghambat yakni; a) kesiapan sumber daya masih rendah, karena kurangnya jumlah staff dan keterampilan jumlah staff sebagai pelaksana program di lapangan, dan adanya permasalahan dalam bidang finansial program, b) dukungan peraturan yang belum memadai, c) kondisi lingkungan kebijakan (sosial ekonomi program) yang terhambat dengan adanya karakteristik masyarakat miskin pesisir yang cenderung jatuh dalam lingkaran kemiskinan, dan d) ketidak patuhan birokrat pelaksana di tingkat lapangan dalam merealisasikan program sebagimana amanat perda. 
Dan terakhir; berkaitan dengan pertentangan antar aktor kebijakan dipicu dengan munculnya penolakan LKM untuk menyalurkan dana bergulir samisake kepada penerima pinjaman melalui rekening bank. Kondisi ini melahirkan diskresi yang pada akhirnya malah menimbulkan hambatan baru dalam perjalanan implementasi program kebijakan. Dari diskresi tersebut legislator merespon secara proaktif dengan merancang Raperda Dana Bergulir Samisake lebih mendetail.

\section{Perbaikan Program}

Pada dimensi perbaikan program diketahui bahwa: Pertama; Pada aspek ketercapaian program terhadap tujuan program, maka secara matematis program ini telah menunjukan kinerja yang optimal pada tahun petama dengan persentase shortterm outcome sebesar $23 \%$. Hal ini dengan mengacu pada model monitoring yang dikembangkan oleh Riant Nugroho (2011:667) tentang skuensi antara perencanaan dan evaluasi, peneliti menganalisis target capaian program yang telah dihasilkan dalam proses implementasi program dana bergulir samisake ke dalam gambar sebagai berikut:

\section{Gambar 3 Analisis Kesesuaian Target dan Hasil Capaian Program}

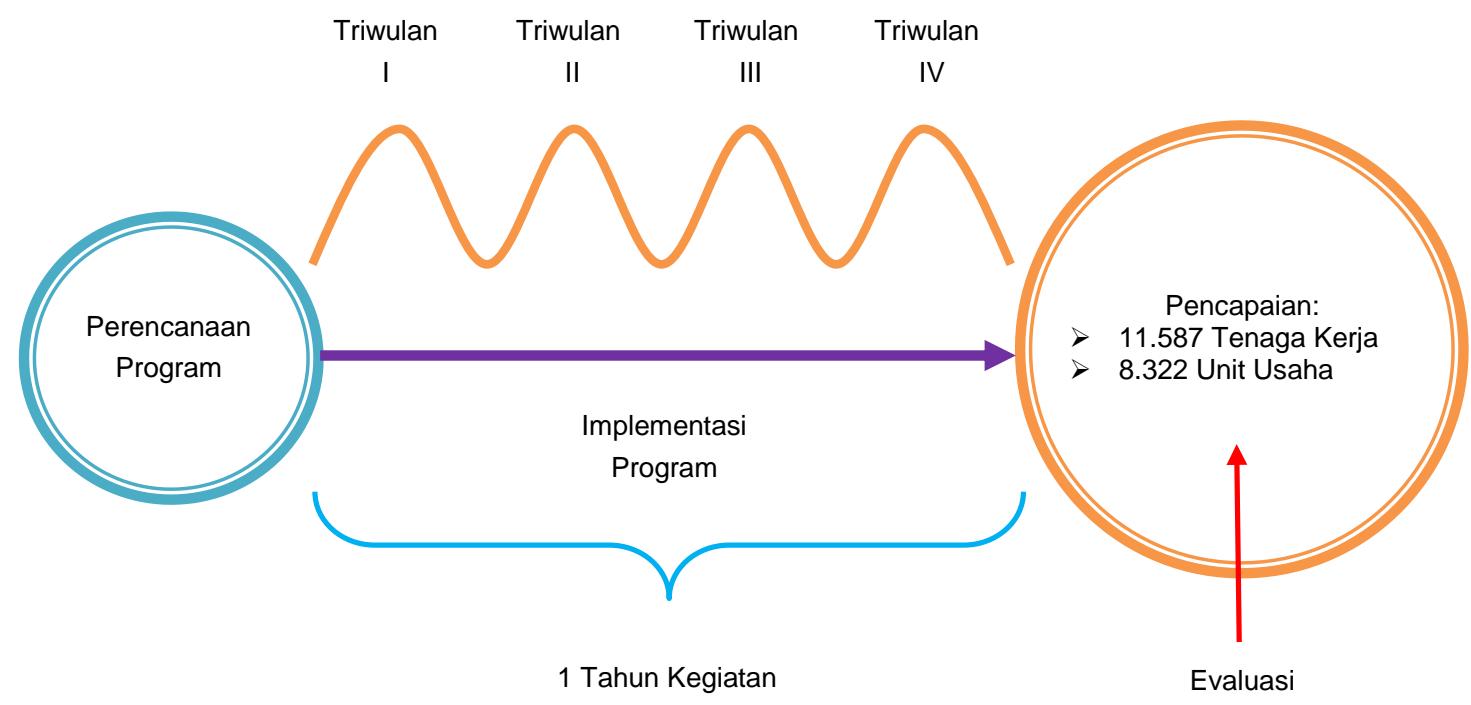

Kedua; Terdapat tiga wilayah program yang menjadi fokus dalam modifikasi yaitu; (a) wilayah pertama merupakan usulan dari legislatif untuk memperbaiki mekanisme penyaluran dana bergulir, (b) wilayah kedua merupakan keinginan dari birokrasi (Pemerintah Kota Bengkulu) untuk melakukan penyempurnaan dimensi pendampingan program, dan (c) wilayah terahir merupakan harapan dari UPTD dalam aspek pemenuhan sumberdaya manusia/staff pelaksana baik dari segi kualitas maupun kuantitas personel. Hal ini sebagaimana terlihat pada gambar sebagai berikut: 

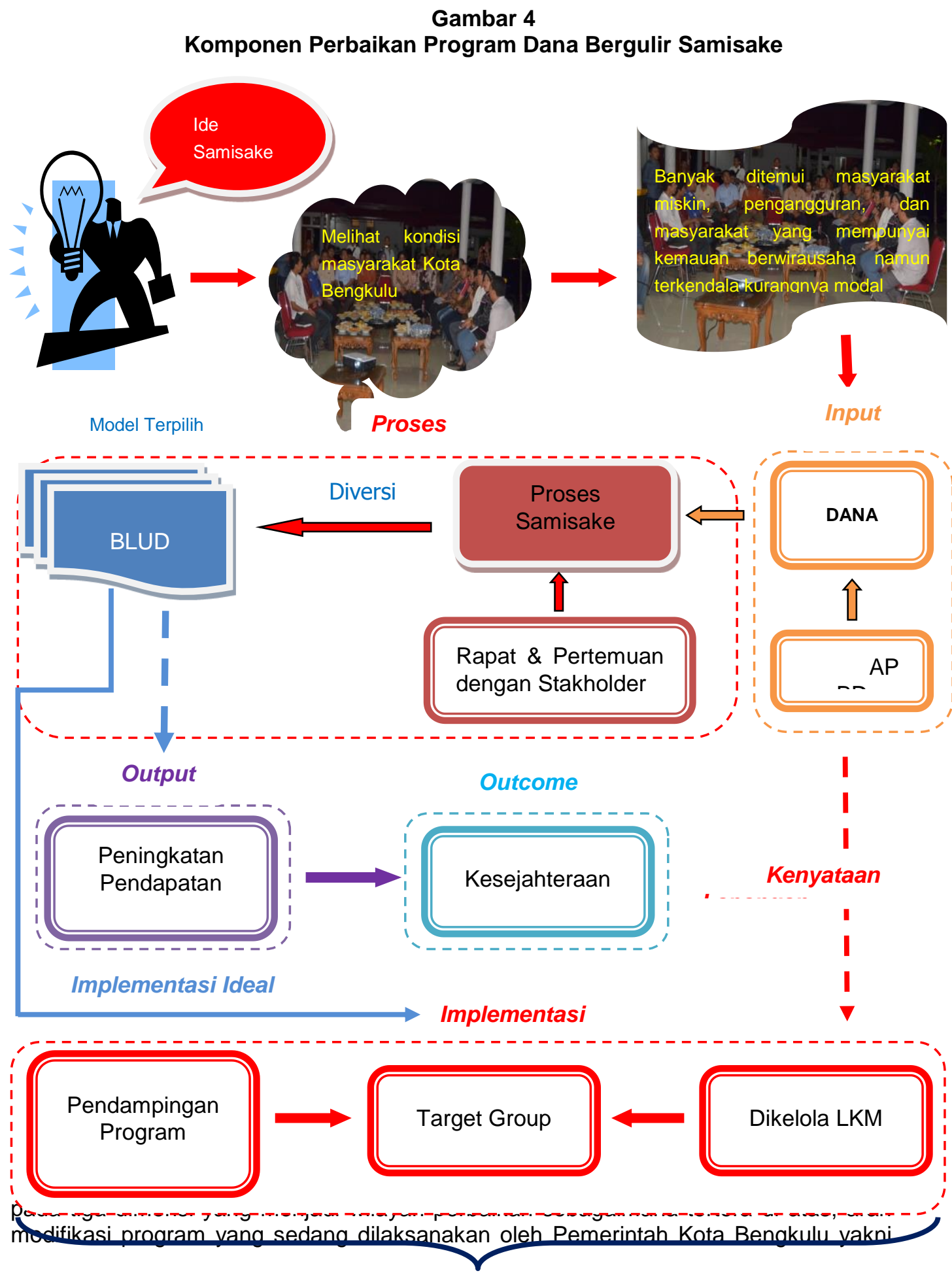

Wilayah Perbaikan Program 
dengan membahas revisi Peraturan Walikota Nomor 12 Tahun 2013 tentang Dana Bergulir Samisake yang prosesnya sampai dengan saat ini masih dalam pembahasan oleh Panitia Kusus Raperda Dana bergulir Samisake di DPRD Kota Bengkulu.

Adapun point krusial dalam pembahasan tersebut adalah pembahasan tentang pembentukan Badan Layanan Umum Daerah (BLUD) sebagai lembaga yang akan mengelola dana bergulir samisake secara penuh. Adapun terkait dengan wilayah perbaikan pada dimensi yang lain menurut informan baik dari perwakilan birokrasi maupun legislatif akan masuk dalam pembahasan Raperda Dana Bergulir Samisake yang prosesnya sampai dengan penelitian ini berlangsung masih dalam tahapan pembahasan antara pihak eksekutif dan legislatif. Kemudian untuk poin-poin krusial seperti teknis pendampingan program dan permasalahn pengguliran lainya menurut pihak legislatif akan diatur dalam aturan teknis tersendiri pasca' paripurnanya proses "penggodokan/pengkajian" Raperda oleh Pansus di Komoisi II DPRD Kota Bengkulu.

\section{Lesson Learn}

Berdasarkan hasil temuan dalam konteks evaluasi program dana bergulir samisake, maka lesson learn terhadap keberlanjutan program dana bergulir samisake yakni; Pertama; dalam proses implementasi, pertimbangan atas kecukupan instumen pendukung program harus dipandang sebagai syarat yang mutlak. Kedua; intervensi program harus dipandang secara utuh, sehingga tidak menciptakan ambiguitas program di dalamnya, Ketiga; tingkat pemahaman street-level bureaucrats harus menjadi perhatian serius bagi birokrasi, karena dapat menyebabkan terjadinya ketidak patuhan baik di tubuh street-level bureaucrats sendiri maupun bagi target group. Terakhir; faktor lingkungan kebijakan dalam konteks implementasi perlu mendapatkan perhatian yang cukup, hal ini mengingat program pro-poor terdahulu yang cenderung mengalami kegagalan dari dimensi ini.

\section{KESIMPULAN DAN SARAN}

\section{Kesimpulan}

Berdasarkan hasil dan pembahasan dari penelitian dengan judul "Evaluasi Implementasi Program Dana Bergulir Samisake di Kota Bengkulu". maka dapat ditarik kesimpulan sebagai berikut:

1. Pada dimensi implementasi program, teridentifikasi sebagai berikut:

a) Proses implementasi program tidak sesuia dengan rencana awal program. Hal ini dillihat dari proses pengguliran program yang langsung dialokasikan dari dana APBD melalui Kas Daerah langsung kepada LKM, tidak melalui BLUD

b) Output Program : a) jenis layanan berbentuk pendampingan teknis, b) jumlah kelompok sasaran telah menghasilkan sebanyak 9294 orang, dan c) keterserapan jumlah dana sebesar Rp 13.649.000.000,00.

c) Dalam proses implementasi program dana bergulir samisake di lapangan menghasilkan short-term outcome sebanyak 11,587 orang, dan 8,322 unit usaha.

d) Hambatan yang ditemui dalam proses implementasi program yakni; a) kurangnya kesiapan sumber daya program, b) dukungan peraturan yang belum memadai, c) kondisi lingkungan kebijakan (sosial ekonomi program), dan d) ketidak patuhan birokrat pelaksana di tingkat lapangan.

2. Pada dimensi perbaikan program diketahui bahwa:

a) Aspek ketercapaian program telah menunjukan kinerja yang optimal pada tahun petama dengan persentase short-term outcome sebesar $23 \%$. 
b) Tiga wilayah program yang menjadi fokus dalam modifikasi yaitu; (1) perbaikan mekanisme penyaluran dana bergulir, (2 penyempurnaan dimensi pendampingan program, dan (3) pemenuhan sumberdaya manusia/staaf pelaksana baik dari segi kualitas maupun kuantitas personel.

c) Adapun perkembangan terhadap modifikasi program baru sampai pada tahap perumusan raperda yang sedang dibahas oleh pemerintah (eksekutif dan legislatif)

\section{Saran}

\section{Saran bagi Para Akademisi/Peneliti}

Penelitian tentang evaluasi kebijakan, khususnya evaluasi program merupakan bagian yang sangat vital guna mengetahui permasalahan yang terjadi dalam konteks implementasi dan merupakan bagian vital dalam proses modifikasi program pasca implementasi. Sebagai bentuk keberlanjutan dari jenis penelitian evaluasi program diharapkan bahwa penelitian selanjutnya dapat mengulas tentang evaluasi dampak kebijakan ketika umur kebijakan telah memenuhi persyaratan untuk diteliti dalam kajian dampak kebijakan.

1. Saran bagi Pemerintah

Peneliti sangat berharap kiranya pemerintah baik sebagai regulator maupun implementor tidak hanya menjadikan berbagai kebijakan pemberdayaan hanya sebatas slogan dan proyek semata. Melainkan dapat bersifat sustainable sehingga intervensi dari kebijakan yang dikembangkan menghasilkan tingkat ketercapaian sebagaimana termuat dalam tujuan program

2. Saran bagi Masyarakat

Masyarakat diharapkan untuk terlibat aktif di dalam kegiatan intervensi program yang dikembangkan oleh pemerintah, partisipasi di dalam perencanaan, pelaksanaan dan pengawasan kebijakan sangat diperlukan sebagai bentuk umpan balik terhadap pelaksanaan program. Program dana bergulir samisake harus disadari bukan sebagai program hibah (charity), melainkan program dana bergulir yang bersifat sustainable yang pada akhirnya diarahkan untuk meningkatkan kesejahteraan bagi masyarakat itu sendiri. Selain itu juga masyarakat diharapkan tetap dapat memberikan "trust" (kepercayaan) terhadap kebijakan yang dicanangkan oleh pemerintah. Hal ini dikarenakan kepercayaan merupakan modal awal untuk mendukung keberhasilan dari intervensi suatu program.

\section{DAFTAR PUSTAKA}

Peraturan Daerah Kota Bengkulu Nomor 12 Tahun 2013 Tentang Petunjuk Teknis Pengelolaan Dana Bergulir Samisake.

Peraturan Daerah Kota Bengkulu Nomor 28 Tahun 2013 Tentang Petunjuk Teknis Pengelolaan Dana Bergulir Samisake.

Parson, Wayne. 2011. Public Policy: Pengantar Teori dan Praktik Analisis Kebijakan. Kencana Prenada Media Group, Jakarta.

Wholey, Joseph S, Harry P. Hatry, Kathryn E Newcomer. 2004. Handbook of Practical Program Evaluation. John Wiley \& Sons, Inc, San Fransisco.

Nugroho, Riant. 2011. Public Policy. Elex Media Komputindo, Jakarta. 